to the petiole. These were finely chopped, and tested for antibiotic content in the usual manner with bacteria-seeded test plates. A well-marked concentration of penicillin was found to have entered the leaves in only $45 \mathrm{~min}$., whereas streptomycin could not be detected after four hours.

Such facts are satisfactorily explained by supposing the xylem elements to be negatively charged. As such they would hinder, or prevent, the intake of basic organic moleculos, which are positively charged, while not interfering with, or even accelerating, the intake of negatively charged acidic molecules. There seems to be no reason why this condition should not prevail in the intact xylem system; but it would scarcely affect such mobile positively charged particles as the sodium or potassium ions commonly found there.

The origin of the charge is possibly as follows ${ }^{1}$ : negatively charged $\mathrm{OH}^{\prime}$ ions, formed from ionized water molecules, induce a dipole separation of charges in the non-ionizing cellulose and lignin of the xylem. This polarization causes an attraction to arise between the $\mathrm{OH}^{\prime}$ ions and the xylem surface, which is sufficiently great to overcome the thermal energy of the ions. Consequently, the $\mathrm{OH}^{\prime}$ ions are bound to the xylem surface, which thus becomes negatively charged. For explanation of the special ability of anions, particularly $\mathrm{OH}^{\prime}$ ions, to induce charged surfaces of this type, ref. 1 should be consulted.

Petiolar feeding of leaves may be said to have as its objective the administration of substances to the mesophyll cells in the most 'natural' way. The above results suggest that the method may be unsuitable for administering basic substances, in which case infiltration technique should be used.

It might further be added that while acidic substances, as judged from rapid petiolar intake of their solutions, enter the xylem with ease, this is no guarantee that they obtain rapid access to the chlorophyll-containing cells. Speed of access to these cells will be determined by the semi-permeable properties of the close-fitting cells sheathing the xylem and its branches; for an unstable substance like penicillin any considerable delay would be serious.

Oxford Medicinal Plants Scheme,

Department of Botany,

Oxford. Dec. 17.

'Alexander and Johnson, "Colloid Science", 1, 45 (Oxf. Univ. Press, 1949).

\section{Orientation of Telotrematous Brachiopoda}

A STUDY of the development of the rhynchonellid, Tegulorhynchia nigricans, Sowerby, shows the larva to be furnished with two pairs of large tufts of long setæe set on the hind margin of the mantle rudiment. The members of one pair lie dorso-laterally, those of the other pair laterally. On the mid-ventral surface of the larval mantle is a longitudinal thickening of ciliated cells some $70 \mu$ long and reaching to the hind edge. Two bands of muscle fibres pass forward inside the larval pedicle and are finally inserted one each side of the mid-dorsal line of the base of the mantle.

After attachment and mantle reversal, the dorsolateral tufts of setre are found on the edge of the brachial valve near the mid-line, and the lateral tufts are found laterally on the edge of the pedicle valve. Lying mid-longitudinally on the inner face of the pediele valve is a short cellular thickening which is probably derived from that on the mid-ventral side of the larval mantle. Adjustor muscles pass between the stalk and the pedicle valve. Other muscle pairs are prèsent, notably the divaricators. It is clear that the ventral part of the larval mantle gives rise to the pedicle valve of the young adult and that the dorsal portion of the larval mantle provides the brachial valve.

The fact that immediately after mantle reversal a pair of adjustor muscles passes between the stalk and the pedicle valve shows that the larval muscle bands consist of more than adjustor elements and that their inner portions give rise to other muscles, those likely being the divaricators, the upper ends of which lie alongside the ends of the adjustors inserted on the pedicle valve.

The well-marked features of the late larva of Tegulorhynchia make possible the ready rolation of the external structures of that phase with those of the young adult immediately after metamorphosis.

In the case of Terebratella inconspicua Sowerby, the development of which has been described ${ }^{2}$, the larva possesses little externally which can be reliably followed through metamorphosis. The setæ are minute, few, squarely set about the long axis, and useless for orientation. The median ventral thickening, about $35 \mu$ long, has not been traced immediately after reversal ; but a small thickening appears on the inner face of the pedicle valve when the mouth forms, and projects somewhat into the latter. Whether this is a reappearance of the original thickening is not certain. The guide through metamorphosis for orientation was taken as the pair of muscle bands in the larval pedicle, passing forward to the dorsal side. These muscles were considered to become the pair of adjustors of the young adult, thus making the pedicle valve morphologically dorsal.

The observations on the metamorphosis of Tegulorhynchia bring into question the value of the interpretation of the metamorphosis of Terebratella inconspicua. The interpretation of the latter metamorphosis in terms of that of Tegulorhynchia simplifies what would otherwise be complex and is in accord with similarities of other kinds which exist in the two developments.

The earlier interpretation of the metamorphosis of Terebratella is discarded and is replaced by one which makes it agree essentially with that of Tegulorhynchia. The orientation of the two young adult brachiopods is then similar to that of Lingula, as described by Yatsu $^{2}$.

Canterbury University College,

E. Percivat, Christchurch, C.1,

Now Zealand.

Aug. 22

${ }^{1}$ Percival, Trans. Roy. Soc., New Zealand, 74, 1 (1944).

"Yatsu, J. Coll. Sci. Imp. Univ., Tokyo, 17, 1 (1901-3).

\section{Determination of Adrenalin and Noradrenalin in the Human Fœtal Adrenals and Aortic Bodies}

T'HE adrenalin content of the fotal adrenals has been studied in experimental animals by biological and chemical methods to a relatively insignificant extent; corresponding studies on human material are scarce. Lelkes ${ }^{1}$ has shown by biological methods that as early as towards the end of the third fœetal 